\title{
AROLDO DE AZEVEDO (1910-1974).
}

\section{NICE LECOCQ MULLER}

Livre-docente do Departamento de Geografia da Faculdade de Filosofia, Letras e Ciências Humanas da Universidade de São Paulo

O nome de Aroldo de Azevedo é conhecido em todos os rincões do imenso Brasil. Isto se deve a seus livros didáticos de Geografia, pelos quais estudaram alguns milhares de crianças e jovens, hoje em todas as faixas etárias. Como autor de livros didáticos, teve o mérito de introduzir a Geografia dentro de nova didática, que então saiu das emboloradas "corografias" para ingressar na moderna orientação explicativa da ciência geográfica como correlacionamento meio natural-homem.

O nome de Aroldo de Azevedo é respeitado profissionalmente, entre geógrafos do Brasil e do exterior. O título de Doutor Honoris Causa que recebeu da Universidade de Bordeaux materializa esse reconhecimento internacional. Entre os geógrafos brasileiros, foi ele o profissional que enriqueceu nossa bibliografia específica com inúmeros trabalhos, destacando-se os que elaborou no campo da Geografia Urbana, que era o de sua preferência.

O nome de Aroldo de Azevedo representa um marco na história universitária brasileira. Foi o primeiro catedrático de Geografia do Brasil na primeira universidade brasileira - a Universidade de São Paulo. Neste campo, foi para os alunos o mestre conscencioso tanto no preparo das aulas - a que dedicava o maior carinho - como o avaliador equilibrado: o preocupação da justiça foi sempre um dos traços mais marcantes de sua personalidade. Para os colegas do Departamento de Geografia foi o exemplo da ética profissional, o incentivador dos vários trabalhos em equipe que liderou, o elemento de bom senso nas situações difíceis.

O nome de Aroldo de Azevedo estará sempre gravado na memória de tantos quantos tiveram o previlégio de te-lo como amigo. Ele foi o amigo certo das horas incertas, o apoio moral quando imperava o desânimo, a palavra de estímulo quando se implantava a insegurança, 
a mensagem de fé quando o peso de viver parecia demasiadamente grande.

AROLDO DE AZEVEDO: um nome que estudantes de todas as idades, que geógrafos de ontem e de hoje, que universitários paulistas e brasileiros, que seus amigos jamais esquecerão. E um nome ligado a muitas coisas e a muitos. E enquanto essas muitas coisas e esses muitos existirem, ficará presente uma grande lacuna e uma imensa saudade.

NICE LECOCQ MULLER. - Nasceu nesta Capital, onde continua residindo. Licenciada em Geografia e História pela $\mathrm{Fa}$ culdade de Filosofia, Ciências e Letras da Universidade de São Paulo, trabalhou como auxiliar de ensino, voluntária, da Cadeira de Geografia Humana, até 1943. Ocasião em que ent:ou para o quadro de extra-numerários, até passar a 3a. assistente. Em 1946 com a tese Sitios e Sitiantes no Estado de São Paulo, obteve - grau de Doutor em Ciências (Geografia). Vinculada ao curso de Geografia Humana, em 1972 defendeu tese de Livre-Docência. O fator urbano no Vale do Paraiba, Estado de São Paulo. Tese que the conquistou o Prêmio Gago Coutinho da Sociedade Geográfica de Lisboa. Em seguida solicitou aposentadoria como Livre-Docente do Departamento de Geografia da Faculdade de Filosofia, Letras e Ciências Humanas da Universidade de São Paulo.

Entretanto "continua prestando serviços à comunidade nos seguintes cargos: Presidente da Câmara de Ciências Humanas do Conselho Estadual de Cultura da Secretaria de Cultura, Esporte e Turismo. Vem participando de trabalhos de planejamento recente: Plano Integrado de Manaus, Plano de Desenvolvimento da Amazônia, Plano de Desenvolvimento da área metropolitana de Belem. 